\title{
The Issue of a Transport Mode Choice from the Perspective of Enterprise Logistics
}

https://doi.org/10.1515/eng-2019-0044

Received Mar 14, 2019; accepted May 15, 2019

\begin{abstract}
The paper includes the research outputs in the area of examining the total costs of delivering products to the customer for a particular transport mode choice. The methodology of choice procedure is presented based on the calculation of threshold distance for different variants of shipments in road and rail transport based on delivery costs. The paper also assesses the possibility of compiling a multi-criteria function for enterprise logistics, that beside the costs takes into account also other aspects as rail transport availability, time for loading and unloading, shipping time or environmental impacts.
\end{abstract}

Keywords: transport mode, decision-making, delivery costs, threshold distance

\section{Introduction}

Within enterprise logistics, an important strategic issue is to decide on the transport mode being used to transport products, materials or components for assembly to the customer. This requirement for product delivery may be a part of one-off or long-term contracts and it may be incorporated into the contract by using a delivery clause Incoterms ${ }^{\circledR} 2010$, e.g. DAP - delivered at place (to the specified destination). In decision-making process on what type of transport used in enterprise logistics will be preferred, it is necessary to have knowledge of procedure of calculating the total delivery costs [1]. The paper contains the published research outputs in this area and the proposed procedure to determine so-called threshold distance, i.e. the distance from which a particular transport mode is more advantageous in terms of the total delivery costs $[2,3]$.

^Corresponding Author: Stefania Semanova: University of Zilina Zilina, Slovakia; Email: stefania.semanova@fpedas.uniza.sk Jozef Gnap, Milos Poliak: University of Zilina Zilina, Slovakia
The European Union has published its plans in the White Paper [4]. It plans to create a single European transport area and a competitive transport system that uses resources efficiently. One of the plans is that $30 \%$ of road freight over $300 \mathrm{~km}$ should shift to other modes such as rail or waterborne transport by 2030, and more than $50 \%$ by 2050. Efficient and green freight corridors would facilitate achieving this goal. If the plan is achieved, this will contribute to shifting the threshold distance down (the distance from which rail transport or water transport is more favourable compared to road freight transport) and the proposed procedure for determining the threshold distance will be even more important. By 2020, the EU is to develop a common approach to internalise the costs of noise and local pollution across whole rail network [4]. Within internalisation of the costs of noise, it can be expected that rail freight transport will be disadvantaged, especially if rail corridors pass through populated areas and trains are operated at night hours when stricter noise limits apply.

In terms of enterprise logistics, it is first necessary to assess technological possibilities on the production side, packaging lines, loading equipment and often the restrictive requirements of customers to whom the product that enters into the next production process is delivered. For instance, this can relate to the maximum weight of goods on one pallet regarding to the limitations of handling equipment and production line. These data enter in deciding on the transport unit size and based on that load distribution on transport means that are considered is proposed $[5,6]$. Therefore, the paper includes the application of the proposed procedure for determining the threshold distance including the issue of load distribution in the case of a particular transport units (IBC containers) on particular transport means.

A number of other requirements may enter into decision-making process on the use of a particular transport mode. Some of them may be limiting such as the free capacity of railroad at the required loading and unloading times according to customer needs. This basically represents a problem of multi-criteria decision-making that is also used in logistics [7]. Therefore, it is necessary to take into account more criteria in actual decision-making tasks,

ð Open Access. () 2019 J. Gnap et al., published by De Gruyter. (cc) BY This work is licensed under the Creative Commons Attribution 4.0 License 
for example, importance of shipment time, possible risks that may disrupt the continuity of supply of materials and components to the production (e.g. frequent traffic congestion, possible repairs of bridges and thus detour routes), customer's requirements for packing the shipment into a transport unit due to its possibility for unloading and its technological line. When deciding on the choice of transport mode and particular transport mean or implementation of real logistics process, it is necessary to utilize the cutting-edge decision-making techniques and potential engineering applications that can evaluate a wide range of data gathered on-line within the logistics chain e.g. monitoring of freight vehicles in road transport as well as wagons in rail transport, camera systems at places of loading and unloading, enterprise systems of individual processes such as time of weighing, data on weight at enter and exit from the loading place, weight and etc. [8].

\section{Methodology of Decision-making on Transport Mode and Carrier}

Economic constraints, limited resources, competitive pressure and customers' demands force undertakings to take the most effective and productive decisions on the choice of transport mode and carrier. Given that transport affects customer service, shipping time, service reliability, stocks, packaging, storage, energy consumption, pollution (caused by transport) and other factors, transport management must create the best transport strategy.

When deciding on the choice of transport mode or carrier, four separate phases can be distinguished:

- recognizing the problem,

- process of exploring the options,

- process of making a choice,

- subsequent assessment.

Recognizing the problem represents the initial stage in the process of making a decision on the choice of transport mode (carrier) and this can be triggered by a number of different factors: customer requirements, dissatisfaction with the existing mode of transport or changes in the company's model of distribution. The most important factors usually have some connection with the customer service. After recognizing the problem, it is possible to start the phase of exploring possible alternatives, unless the customer insists on a particular transport mode.

Within the process of exploring options, the relevant managers assess various sources of information that may help them to make the optimal decision on the choice of transport mode (carrier). The possible information sources may consist of past experiences, sales representatives of carriers, company records of realized deliveries or company customers. Once a sufficient amount of relevant information is collected, it is possible to make a decision and to choose the optimal alternative of transport mode (carrier).

The process of making a choice includes the selection of one of several alternatives of transport modes or carriers that are available. Based on the information gathered in the process of exploring options, managers in the field of transport determine which one of available options best suits the customer requirements for service and it is at acceptable costs. In general, the main determinants in making a choice of transport mode or carrier are the factors related to the level of customer service and costs.

Regarding the criteria used for selection and assessment of carriers within individual transport modes, many similarities exist. The factors such as timely pick-up and delivery of goods, quick response to customer inquiries, reliable shipping time and competitive rates are generally important regardless of transport mode or carrier considered.

A further stage is subsequent assessment. Once the management makes the choice of transport mode or carrier, it must establish certain evaluation procedures by using of which it will be possible to determine the performance level of the selected transport mode/carrier in the future. It is a matter of a particular company whether the assessment process is extremely detailed or may not even exist at all. In the case of most companies, a scope of the assessment process ranges within the mentioned extremes. It seldom happens that the company does not respond at all to customer complaints regarding carriers. Companies usually use other methods in subsequent assessment, e.g. cost analysis, audits, examining timely pick-ups and deliveries of shipments. Some companies conduct a statistical analysis of quality indicators of transport service provided by the carrier, e.g. timeliness of delivery or a range of losses and damages.

The choice of transport mode and carrier is becoming increasingly important aspect of logistics management because, for example, production companies are generally trying to reduce the number of carriers whom they cooperate with and they create a system of several key carriers or freight forwarders. Within the process of preparing the logistics project and selecting the transport mode or carrier, it is necessary to optimise transport routes or optimise minimum order quantities of products from the side of customers and etc. $[6,9,10]$. 


\section{Principles of Making a Choice of Transport Mode based on Delivery Costs}

The principle of market economy management based largely on indirect management tools provides individual shippers with the freedom of making a choice of transport mode used. This means that the choice of transport mean is in the competence of companies or their logistics departments, but establishing the assessment criteria is important in the decision process. In the case of indirect way of management, the main criterion is based on the costs incurred on the side of the consignor depending on a particular delivery clause Incoterms ${ }^{\circledR} 2010$ contracted [1]. In particular cases of assessing effectiveness of possible variants of transport modes, it is necessary to take into account not only the costs of the carrier (transport costs) but also delivery costs as a part of the total costs for circulation of goods. In some cases, it may happen that the circulation costs cannot be ascertained due to insufficient background materials and information. Therefore, the sufficient baseline is to have knowledge of the delivery costs.

Delivery costs can be calculated as:

$$
\mathrm{C}_{d}=\mathrm{C}_{P}+\mathrm{C}_{L}+\mathrm{C}_{T}+\mathrm{C}_{U}[€]
$$

Where:

$\mathrm{C}_{d}$ - delivery costs

$\mathrm{C}_{P}$ - shipment packaging costs depending on type of han-

dling and transport mode

$\mathrm{C}_{L}$ - costs of loading depending on transport mode

$\mathrm{C}_{T}$ - transport costs

$\mathrm{C}_{U}$ - costs of unloading depending on transport mode

The costs for circulation of goods include all cost items besides the delivery costs also costs for storage, sorting and distribution of goods.

Some parts of the delivery costs can be valued at the consignor costs and others can be valued according to the tariff (e.g. price ranges of particular transport mode or in regard to in-house transport it should be valued based on its own costs).

Only in a small number of cases, production companies decide under consideration of minimizing the delivery costs. In particular, they generally do not know conditions on the side of the consignee and value data about them. However, in many cases, they have insufficient insight into the possibilities of shipment transport and price or cost ranges concerned.

Especially in cases of a larger volume of transport for a particular customer, it is necessary to create conditions for the calculation of a so-called threshold distance for individual carriage ways that are taken into account for this customer. To determine the threshold distance, knowledge on individual elements of relocation and their cost valuation are necessary.

Production companies have various options of transport ways according to their specific conditions. A typical example is the combination of road and rail transport in the case that the consignor of the shipment has available a railway siding and the consignee does not have it. This essentially represents a modal split between direct road transport and one-leg or two-leg combined transport by road and rail transport.

Within the conditions of companies in the Slovak Republic as well as the Czech Republic where the possibilities of inland waterway transport are small, we can model the delivery costs in the following variants:

- rail transport (the consignor and the consignee have railway siding available),

- direct road transport,

- one-leg combined transport (this means that the consignor or the consignee has a railway siding available),

- two-leg combined rail - road transport (neither the consignor nor the consignee do not have railway sidings),

- combined transport with the use of containers,

- road transport with the possible used of accompanied or unaccompanied combined transport if it is possible in a given transport route,

- the use of the technology of swap bodies used in road and rail freight transport.

The basis of the economic calculation of the threshold distance is the modelling of individual elements of the technological process considering the above variants and their cost valuation.

To determine the threshold distance, it is preferable to use the graphical method. The threshold distance is the intersection of curves of the delivery costs e.g. direct road transport and rail transport. According to the graphical representation (Figure 1), it is preferable to used road transport until reaching the given threshold point ("TD" on the $\mathrm{x}$-axis). Then, rail transport is more advantageous for the distance of over this point.

Figure 1 depicts the cost assessment from the consignor to one consignee. If there are more consignees, the delivery costs especially in the area of shipment transport costs will change with respect to different transport routes and thus also costs will change in items such as toll, fuels, driver wage and daily allowance, etc. $[2,11,12]$. 


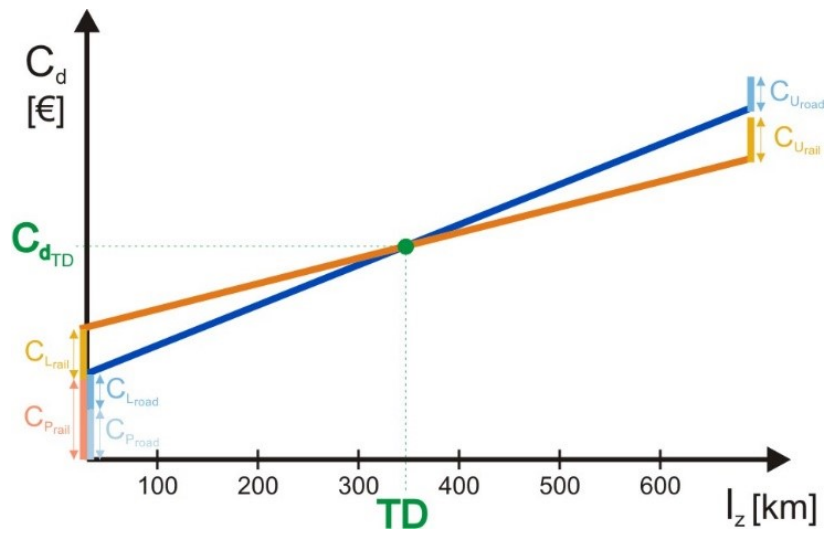

$\mathrm{C}_{d}$ - delivery costs $[€] ; \mathrm{l}_{z}$ - transport distance $[\mathrm{km}] ; \mathrm{C}_{\text {Proad }} / \mathrm{C}_{\text {Prail }}-$ packaging costs in road transport/rail transport [€]; $\mathrm{C}_{\text {Lroad }} / \mathrm{C}_{\text {Lrail }}-$ costs of loading in road transport/rail transport [€]; $\mathrm{C}_{\text {Uroad }} / \mathrm{C}_{\text {Urail }}-$ costs of unloading in road transport/rail transport [€]; TD - threshold distance $[\mathrm{km}]$

Figure 1: Graphical representation of the determination of the threshold distance based on the delivery costs from the consignor to the consignee [authors]

Packaging costs are influenced by the following factors:

- dimensions and weight of packed cargo,

- packing construction,

- packaging material,

- bulk density (space that the product occupies during transport),

- type of cargo (special requirements for packing of dangerous shipments under ADR).

The decisive cost factor in packaging optimization is transport density of the package/shipment which is the weight per cubic meter. Carriage of 100 kilograms of feather can be more expensive than carriage of 100 kilograms of bearings. Designing a shipping packing by using of which cargo fits better on the pallet or freight vehicles decreases transport costs. By this way, it is possible to reduce the costs of packaging material, storage and transport by $10 \%$. According to FedEx, the biggest current trend in logistics is to reduce packing density. This means that companies that do not pack their products effectively must pay more. The shipment has the optimum package size when the bulk density is as close as possible to the actual weight of the package. Transport and logistics companies determine the costs of carriage based on the actual shipment weight.

Material costs represent on average $60 \%-80 \%$ of the total costs of packaging. Material costs depend on various parameters such as type, quality, construction or manu- facturer. It may appear at first sight that the less packaging material, the lower costs, but ultimately, it does not have to be like that. From the point of view of the functional properties of the package itself, the exact opposite is true. The compromise is to find a balance between the construction/design and the size of packaging. Different construction of the same volume sometimes needs a different amount of material. In the case of some types of material, the "exchange" of height and width of packaging can save $20 \%$ of the material used. Optimization of packaging dimensions optimizes also the costs and also it is possible to reduce waste and to get cheaper transport [3].

To verify the proposed method for determining the threshold distance, the authors of the paper carried out a study related to the distance from which rail freight transport is more advantageous within the Slovak Republic for the transport from railway station Cierna nad Tisou (border and transhipment node with Ukraine) to Bratislava central train station. The distance between these two stations is $537 \mathrm{~km}$ and railway wagon Habbins 2799 with the capacity of 63 europallets was considered for the carriage. To transport the shipment by road, an articulated vehicle with the capacity of 33 europallets was taken into account.

Table 1 provides the delivery costs that incur to a consignor and the costs are calculated to one transport unit europallet. Some of cost items are calculated only for rail freight transport such as preparing the wagon for loading and ascertaining the weight of wagon together with the consignment. In this study, Tariff TR1 of rail transport operator ZSSK CARGO was taken into account. This tariff is applicable for national transport of wagon consignments in the Slovak Republic.

The higher packaging costs in rail transport are associated with greater demands on the consignor also in terms of checking the take-over the loaded wagon for transport from the side of rail transport operator as well as stricter regulations. Also, the higher loading costs are incurred due to the fact that the cargo is secured in rail transport by lasing straps supplied by the consignor and they will not

Table 1: The costs calculated in $€$ to one europallet by transport mode [authors]

\begin{tabular}{lcc}
\hline Costs / Transport Mode & $\begin{array}{c}\text { Road } \\
\text { transport }\end{array}$ & $\begin{array}{c}\text { Rail } \\
\text { transport }\end{array}$ \\
\hline Preparing the wagon for loading & - & 0.24 \\
Weighting & - & 0.29 \\
Packaging & 10.4 & 13.00 \\
Loading & 1.95 & 2.15 \\
Total costs per 1 pallet & 12.35 & 15.67 \\
\hline
\end{tabular}


be returned. In road transport, the used fastening means are owned by the carrier and they are included in the transport price.

Figure 2 depicts the graphical representation of threshold distance determination based on the delivery costs from the consignor to consignee applied to a particular case in the Slovak Republic.

According to the method used, rail freight transport is more advantageous for the consignment concerned for transport of over $422 \mathrm{~km}$ in the case of using rail wagon of type Habbins 2799 with the capacity of 63 europallets. The x-axis in Figure 2 includes the distance value of $601 \mathrm{~km}$ because this is the last category of tariff distance in Tariff TR1 CARGO (601 and more) which is used for national rail transport in terms of the area of the SR.

The mentioned graphical method was also verified within the solution of ChemLog project [3].

\section{Application of the Proposed Procedure for Determining the Threshold Distance in Transport of Chemical Substances in IBC Containers by Road and Rail Transport}

The authors of the paper applied the proposed procedure for determining the threshold distance to the following real case study based on the outputs of the ChemLog project [3]. For transport of shipments to the customers requiring a larger volume of chemicals in IBC containers with shipping time not being a decisive factor, it was necessary to calculate whether the transport in large-volume wagons by rail transport is more advantageous than carriage by road transport using semitrailers.

Within enterprise logistics, there is the requirement for choosing a particular transport mean with regard to product packaging and the total weight of one shipping package of the product. In the case considered, it was a unified IBC container with a volume of 1000 litres of chemicals.

In terms of road transport, flatbed semitrailers with sidewalls and headboard or box body semitrailers are suitable for carriage of IBC containers because they block the cargo against movement to the sides. However, it is not possible to achieve the target payload of $25 \mathrm{t}$ in the case of box body vehicles because the own weight of this vehicle is higher compared to the flatbed vehicles.

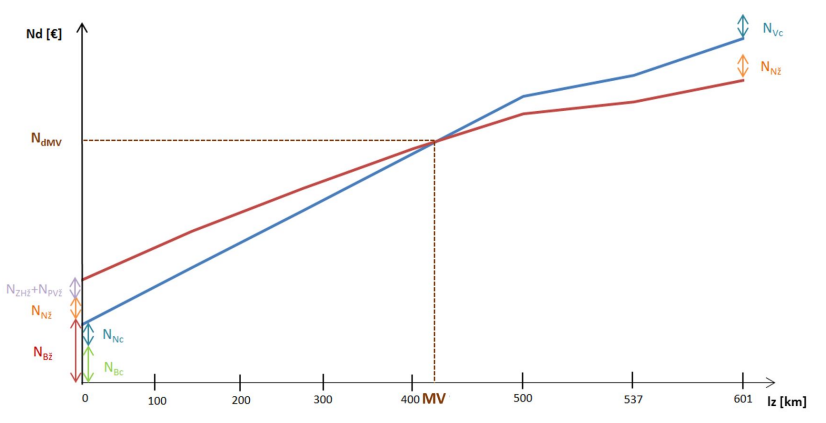

$\mathrm{N}_{d}$ - delivery costs [€]; $\mathrm{l}_{z}$ - transport distance $[\mathrm{km}] ; \mathrm{N}_{B c} / \mathrm{N}_{B}$ - packaging costs in road transport/rail transport [€]; $\mathrm{N}_{N c} / \mathrm{C}_{N}$ - costs of loading in road transport/rail transport [€]; $\mathrm{N}_{V c} / \mathrm{N}_{V l}$ - costs of unloading in road transport/rail transport [€]; MV - threshold distance [km]

Figure 2: Graphical representation of threshold distance determination based on the delivery costs from the consignor to consignee applied to a particular case in the SR [authors]

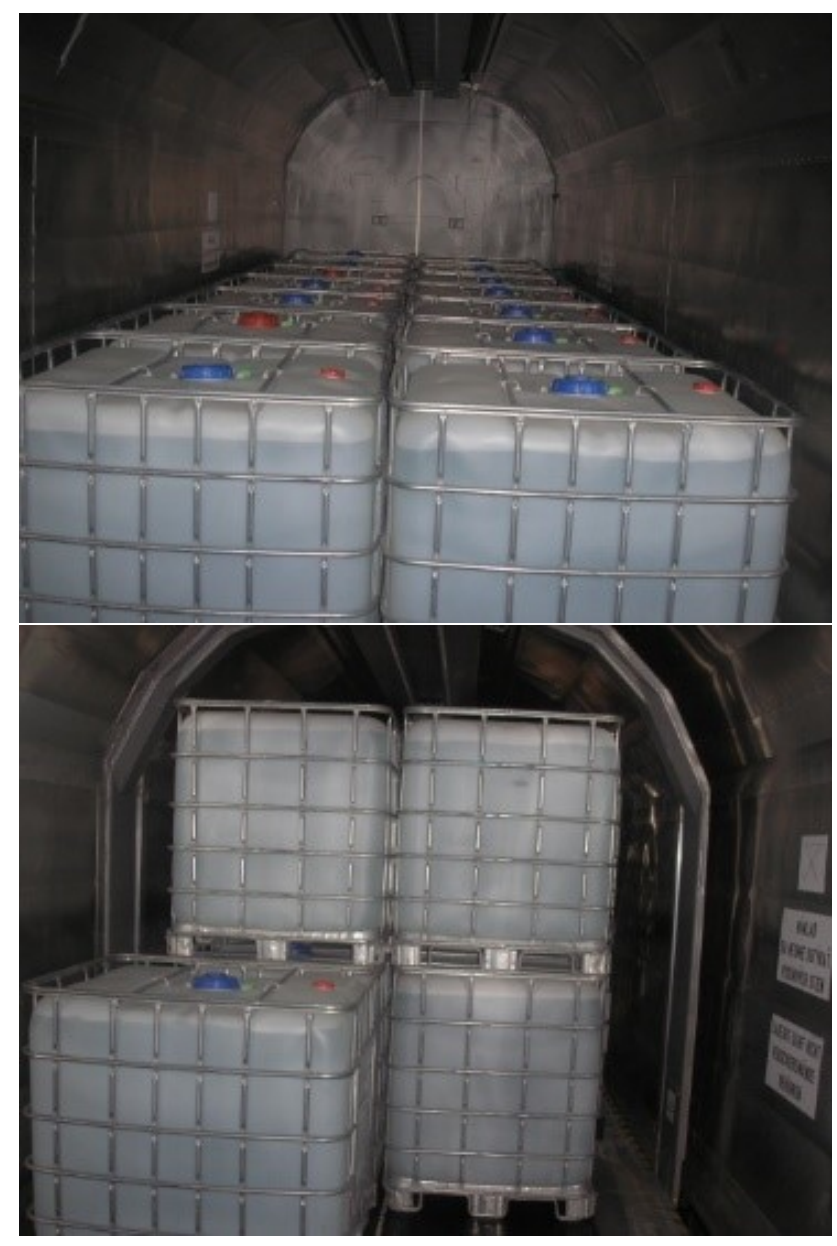

Figure 3: Loading of IBC containers into the railway wagons Habbillns [3] 
The aim of the project solution was to reduce the number of road vehicles needed for carriage of IBC containers to the customers and thus to decrease transport costs related to carriage realized by using semitrailers. Also, the objective was to calculate threshold distance above of which rail transport is more preferable.

When transporting chemicals in IBC containers weighing $1135 \mathrm{~kg}$, it is possible to load a maximum of 21 IBC containers into the semitrailer and 52 IBC containers into the railway wagon Habbillns. The main technical parameters of compared transport units are given in Table 2.

Table 2: The main technical parameters of compared transport units [authors, 3]

\begin{tabular}{|c|c|c|}
\hline Parameter & $\begin{array}{l}\text { Semitrailer } \\
13.6 \mathrm{~m}\end{array}$ & Habbillns \\
\hline Loading length & $13620 \mathrm{~mm}$ & $21200 \mathrm{~mm}$ \\
\hline Loading width & $2480 \mathrm{~mm}$ & $2840 \mathrm{~mm}$ \\
\hline Loading height & $2700 \mathrm{~mm}$ & $\begin{array}{c}2800 \mathrm{~mm} \\
\text { (under roof } \\
\text { girder) }\end{array}$ \\
\hline Loading capacity & $24000 \mathrm{~kg}$ & $\begin{array}{c}61200 \mathrm{~kg}(\mathrm{D} \\
\text { category) }\end{array}$ \\
\hline $\begin{array}{l}\text { Number of loaded IBC } \\
\text { containers }\end{array}$ & 21 & 52 \\
\hline Total weight of cargo & $23835 \mathrm{~kg}$ & $59020 \mathrm{~kg}$ \\
\hline
\end{tabular}

More than double number of the IBC containers can be loaded into the railway wagon in comparison with the semitrailer, assuming that rail transport is carried out on the rail track of $D$ class where the maximum load on the wagon is permitted.

Part of the logistics project solution is also the proposal for load distribution of a particular shipment for a particular usable transport mean. The aim of the proposal is to use the maximum payload of transport mean. The Truck Stow software, developed by the Department of Road and Urban Transport of the University of Zilina, was used to design the load distribution of IBC containers. To basic inputs for the calculation and design of load distribution are technical parameters of transport mean i.e. dimensions of loading space, maximum permitted load per axles and the fifth wheel. Other input data relates to the transport unit i.e. dimensions and weight. The y-axis of the load distribution diagram depicts the weight of cargo in kilograms and the $\mathrm{x}$-axis depicts the distance of the centre of gravity from the front of the semitrailer in centimetres. The distribution diagram for a given shipment (IBC containers) and the semitrailer used is shown in Figure 4.

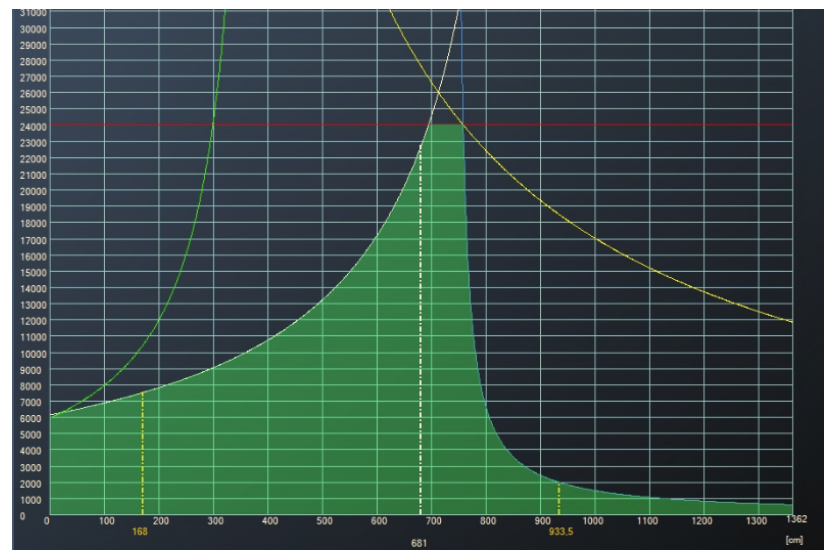

Figure 4: Diagram of load distribution of 21 IBC containers on the semitrailer with payload of $24 \mathrm{t}$ [authors based on Truck Stow and 13]

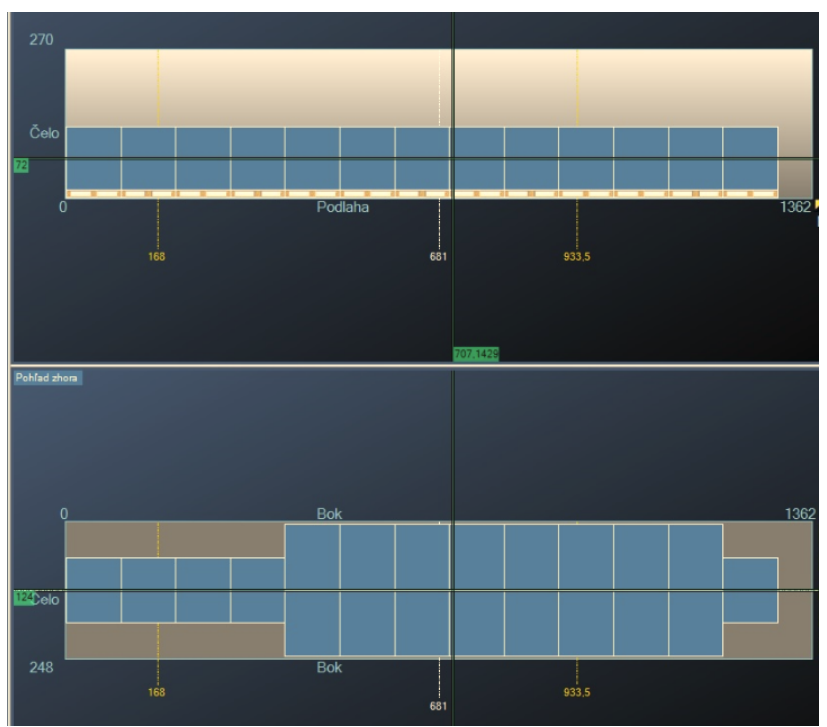

Figure 5: Proposal for distribution of 21 IBC containers on the semitrailer with payload of $24 \mathrm{t}$ (side and top view) [authors based on Truck Stow and 13]

The proposal for distribution of 21 IBC containers on the semitrailer with payload of 24 tons is shown in Figure 5 (side and top view).

If the centre of gravity of cargo lies within the green area, the fifth wheel of the tractor or three-axle of the semitrailer will not be overloaded.

The centre of gravity of 21 IBC containers of $23835 \mathrm{~kg}$ weight lies $707 \mathrm{~cm}$ from the front of the semitrailer, i.e. approximately in the centre of the semitrailer (see Figure 4 and 5).

Figure 6 provides a 3D display of distribution of 21 IBC containers on the semi-trailer.

The railway wagon Habbillns is a wagon with three sliding dividing walls that serve to distribute the pressure 


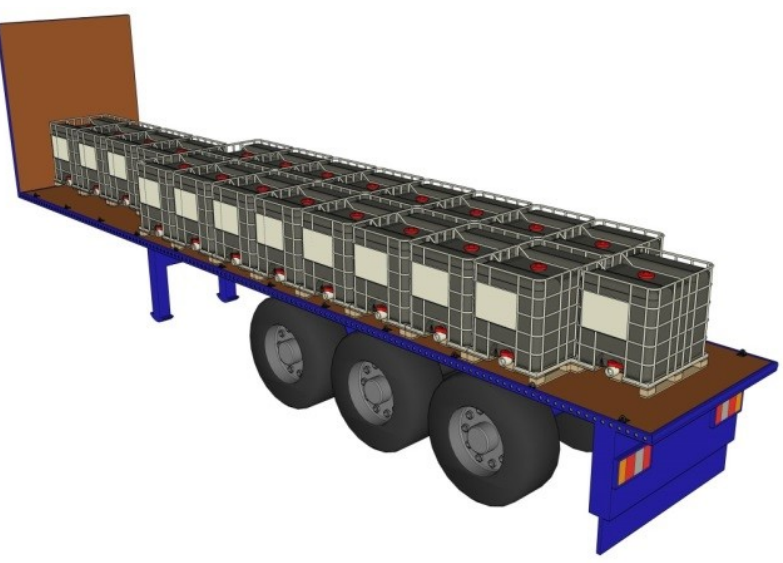

Figure 6: Proposal for load distribution of 21 IBC containers in the case of the semitrailer with payload of $24 \mathrm{t}$ [3]

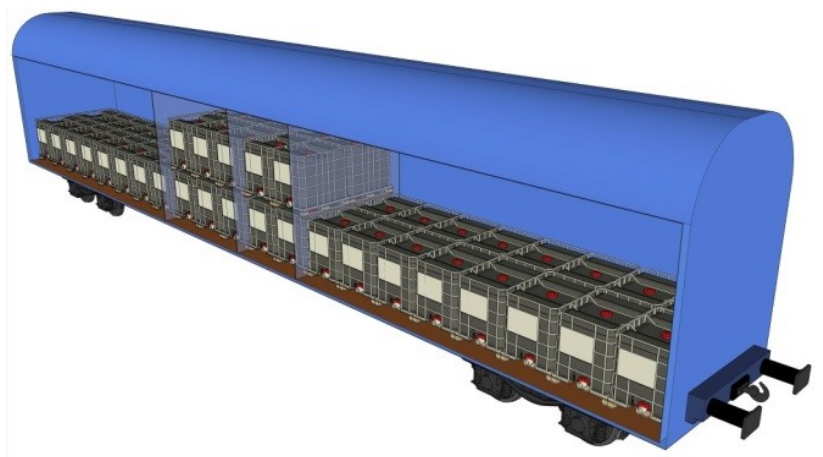

Figure 7: Proposal for load distribution of 52 IBC containers in the case of the railway wagon Habbillns with payload of $59 \mathrm{t}$ [3]

between the cargo and they block cargo in the upper layer against movement in the longitudinal direction. It was necessary to assess whether the load distribution was fine over the entire length of the wagon. For this evenly distributed cargo with the second layer of cargo in the middle, it was necessary to found out whether the permitted payload of $22 \mathrm{t}$ was not exceeded for the distance of $4 \mathrm{~m}$ in the centre of the wagon. This requirement was met because the mentioned payload was at the level of $18.16 \mathrm{t}$ (Figure 7).

For calculation of the threshold distance, only transport costs for a combination vehicle (tractor + semitrailer) within the Slovak Republic for a 24-tonne shipment within the price range of $0.9-1.5 € / \mathrm{km}$ were taken into account. Similarly, the published Tariff rates TR1 of the company ZSSK Cargo Slovakia, a.s. were applied for the used Habbillns railway wagon to determine transport costs in rail transport. The use of wagons of the carrier was considered.

The charge for the use of Habbillns railway wagon was taken into account in the price calculation. According to the Tariff TR1, this charge was $25.75 € /$ transport. This

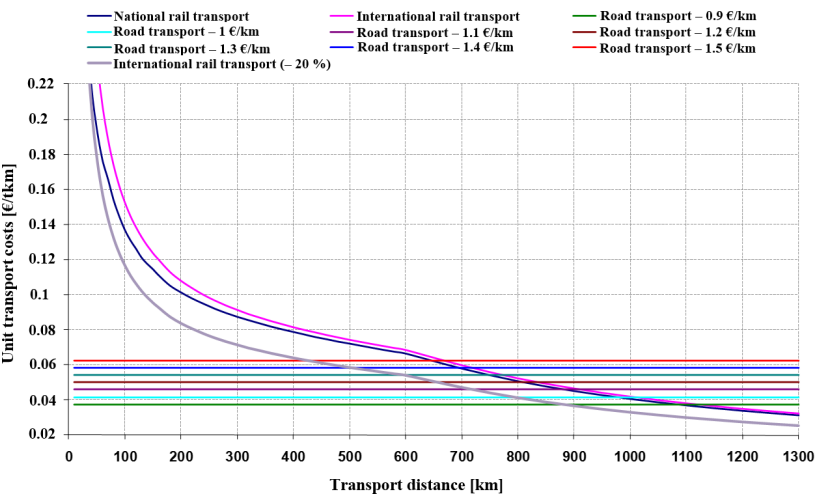

Figure 8: The graph of threshold distance between rail and road freight transport for different prices in road freight transport without the costs for packaging and handling at the place of loading or unloading [authors based on 3]

charge was then calculated for one tonne as follows:

$$
P_{V}=\frac{P V}{Q}=\frac{25.75 €}{59.02 t}=0.436 € / t
$$

Where:

$\mathrm{Pv}$ - charge for the use of a particular railway wagon per one transport and calculated on the weight of the particular shipment $(€ / t)$

$\mathrm{PV}$ - charge for the use of a particular railway wagon per one transport $(€)$

$\mathrm{Q}$ - weight of a particular shipment during the carriage by a particular railway wagon $(\mathrm{t})$

The comparison of threshold distances based on transport price for road and rail transport is provided in Figure 8.

From the perspective of national or international rail transport, this transport mode is preferable only over a certain distance. According to Tariff TR1, this transport mode is preferable only for the transport distance of over 600 $\mathrm{km}$. It should be noted that companies or logistics companies usually agree on more favourable transport prices with railway undertakings in case that they can guarantee certain pre-agreed volumes of shipments over a certain period in order to obtain tariff discounts.

Generally, it can be stated that the higher the prices in road transport, the shorter threshold distance i.e. transport distance from which rail transport is more advantageous. In the case of the unit price $1.2 € / \mathrm{km}$ for the use of a combination vehicle in road transport, the threshold distance for rail transport is $800 \mathrm{~km}$. But, this distance decreases to $650 \mathrm{~km}$ when assuming the agreement on tariff discount of $20 \%$ in rail transport.

The mentioned calculation of threshold distance as is apparent from the comparison of Figure 1 and 8 did not include the costs for packaging of cargo. These costs are con- 
sidered to be the same in road and rail transport because the same IBC containers are used in both transport modes. However, the costs of loading and distributing the cargo onto a particular transport mean are a part of the shipping packaging costs as well as the costs of the consignor. Therefore, differences e.g. in terms of the cost for securing cargo may incur. In the case of railway transport, a greater deceleration arises especially in the longitudinal direction, e.g. during shunting of wagons in marshalling stations, in comparison with road transport. Even in accordance with the standard EN 12595-1, it is necessary to secure cargo in forward direction at the level of $0.8 \mathrm{~g}$ in road freight transport; but if a semitrailer with cargo is transported by rail, the cargo must be secured in forward direction at the level of $1.0 \mathrm{~g}$ ( $\mathrm{g}$ - the gravity acceleration the value of which is $\left.9.780 \mathrm{~m} \cdot \mathrm{s}^{-2}\right)[5,14]$.

Assuming that the consignor has a railway siding available and the place of loading of railways wagons is associated with loading of semitrailers, the same handling (loading) equipment can be used for the same shipment, and therefore the costs of loading at the place of the consignor are the same for one transport unit (IBC container). However, if the total costs per one transport is to be calculated, the costs of loading 52 IBC containers into the railway wagon expressed in absolute terms in $€$ will be higher than costs for loading of the semitrailer.

\section{Multi-criteria Decision-making on the Transport Mode or Carrier}

Various requirements may be included in decision-making on the use of a particular transport mode and some of them may be restrictive, e.g. free capacity of railway transport route at the required times of loading and unloading according to the customer's needs. This is essentially a multi-criteria decision-making process that is used in logistics [7].

In a multi-criteria decision-making, the decisionmaker assesses individual variants through a number of criteria while the objectification of the decision-making process depends on a number of assessment aspects. If the number of evaluation criteria and variants is small, the decision-maker may decide based on intuition. In the case of a greater number of criteria, however, this represents a more complex decision-making situation and it is necessary to apply formalized procedures. A suitable formalized procedure is determination of the weights of evaluation criteria and aggregation of partial evaluations into comprehensive assessment [15]. Within multi-criteria evaluation of variants, Fiala P., Jablonsky J. and Manas M. mentioned that the task is explicitly specified by the set of alternatives $\mathrm{A}=\left\{a_{1}, a_{2}, \ldots, a_{p}\right\}$ (which may include e.g. the possibilities for a choice of transport mode or carrier in our case) and the set of evaluation criteria $\mathrm{F}=\left\{f_{1}, f_{2}, \ldots, f_{k}\right\}$, (which may consists of the criteria such as shipping time, reliability, timely pick-up and delivery, environmental impacts, the delivery costs, etc.) and by the evaluation of the selected variants through individual criteria in the form of so-called criterion matrix (Figure 9) [16].

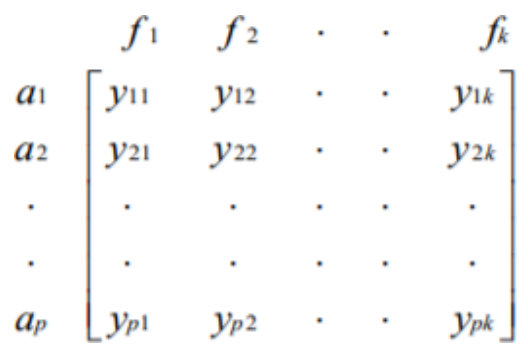

Figure 9: Criterion matrix [16]

The elements of criterion matrix $y_{i j}, i=1,2, \ldots, p, j=1$, $2, \ldots, k$, express information on evaluating alternatives by individual criteria. The information can take the following form:

- cardinal information - represents the actual value that individual variants have achieved in evaluating the given criteria,

- ordinal information - expresses the order of a particular variant according to individual criteria i.e. ordering the criteria by relevance,

- relative information - compares pair variants between each other according to individual criteria [16].

Another criterion for decision-making can be the time of relocation of products from the place of storage in an expedition storage of a production company to the consignee (customer). The costs associated with extending the shipping time due to the change of transport mode must be included in the delivery costs.

In terms of the reverse logistics in the area of returnable transport packaging, it was proposed in the case study, in particular from perspective of the costs, to carry out the reverse transport of empty packages exclusively by road freight transport. The proposed plan for load distribution represented loading of 52 empty IBC containers in two layers into the semitrailer.

Especially, rail transport carriers point out that the transport of separate wagon consignments is ineffective 
for them and they must compensate for losses with other transports carried out. Therefore, the customer must contract for a larger volume of chemicals and makes an order, e.g. for more wagons for a particular transport which may, of course, increase the costs for storage on the side of both the consignor and consignee.

Regardless increased costs of transport, some companies, especially multinational ones, have committed themselves to increase the share of using rail transport that utilises electricity and by this they want to contribute to reducing the impacts of their activities on the environment, e.g. Volkswagen Slovakia.

The criterion representing the impact of a particular way of transport or combination of transport means on the environment enters into the decision-making. In addition to the costs, a so-called carbon footprint for specific transport means used can be calculated [17-19]. In the case of rail transport that uses electricity as a source of energy, the calculation of indirect emissions produced in electricity production can be used [20].

\section{Conclusion}

When assessing individual variants in making a decision on way of transport in particular cases, it is necessary to take into account not only the costs of the carrier (transport costs) but also the delivery costs as a part of the costs for circulation of goods. In this regard, logistics departments of production companies or their providers of logistics services plays an important role. The role of a logistics or freight forwarding company represents e.g. advising the consignor (e.g. machine manufacturer) the most appropriate way of transport to the place of consignee given that the shipments will often be repeated, and for example the machine price includes also the price of transport to the consignee where the machine will be assembled. Freight forwarders should also utilize advantages of combined transport in order to provide better services for their customers taking into account environmental protection. When evaluating the use of combined transport or direct rail or road transport, it is necessary to take into account the possible risks that arise if the production company decides on using only one transport mode. For instance, unforeseen stoppage of transport, e.g. derailment of a freight train near town Krompachy in the SR on the main doubletrack railway line and subsequent exclusion of all transport including passenger transport for 4 days. Another example is accident in railway tunnel in Italy and very long detour. Similarly, in road transport, the carriers can en- counter long detours (e.g. the section of the 1st class road of international importance under Strecno Castle and related detours lasted continuously for 14 days in this case).

In important strategic decision-making about a choice of transport mode or carrier, it is necessary to apply the methods of multi-criteria decision-making. It is recommended so that the decision-maker e.g. logistics department of a production company assesses the individual variants through a number of criteria, while the objectification of the decision-making process depends on a number of assessment aspects and on the accuracy of inputs, for example, in the area of the costs of delivery from the production company to the particular customer.

When deciding on the choice of transport mode and particular transport mean or implementation of real logistics process, it is necessary to utilize the cutting-edge decision-making techniques and potential engineering applications that can evaluate a wide range of data gathered on-line within the logistics chain. In this regard there are several methods such as Collaborative Filtering Bandits [21] or method for assessing the risks associated with e.g. choice of transport means and alternative transport routes [22]. In the application of multi-criteria analysis, the assessment can be supplemented by the other methods [23].

Also, some dangerous shipments are needed to be monitored on-line throughout the logistics chain, even when combining several transport modes [24]. In this regard, it is possible to obtain a variety of data for decisionmaking processes on the choice of transport mode, transport mean, transport route, delays, handling operation times and etc.

Acknowledgement: This paper was developed under the support of project: Centre of excellence for systems and services of intelligent transport II., ITMS 26220120050 supported by the Research \& Development Operational Programme funded by the ERDF

\section{References}

[1] Gnap, J., Poliak, M., Sosedova, J., Jaglecak, J., Zasielatelstvo, 2011, University of Zilina in Zilina: EDIS, ISBN 978-80-554-04073.

[2] Gnap, J., Poliak, M., Kalkulacia vlastnych nakladov a tvorba ceny v cestnej doprave (4th ed.), 2017, University of Zilina: EDIS vydavatelstvo ZU, ISBN-978-80-554-1346-4.

[3] Gnap, J., Jagelcak, J., Gasparik, J., Lizbetin J., et all Feasibility study Development of railway transport of chemicals in Slovakia in relation to adjacent countries and prepared combined transport terminals, 2010, CHEMLOG projekt, Association of chemical 
and pharmaceutical industry of the Slovak republic, University of Žilina.

[4] WHITE PAPER - Roadmap to a Single European Transport Area Towards a competitive and resource efficient transport system, $\operatorname{COM}(2011)$ 144, Brussel.

[5] Jagelcak, J., Kiktova, M., Stopkova, M., The Application of the Verified Gross Mass of Intermodal Loading Units in the Conditions of the Slovak Republic, In: Our Sea, Vol. 65, Issue 4, pp. 218-223, University of Dubrovnik, 2018, DOI: 10.17818/NM/2018/4SI.10.

[6] Kampf, R., Hlatka, M., Bartuska, L., Optimization of Production Logistics, In: Advances in Science and Technology-Research Journal, Vol. 12, Issue 4, pp. 151-156, December 2018, Lublin Univ. Technology, DOI: 10.12913/22998624/100351.

[7] Lebeau, O., Macharis, C., Van Mierlo, J., Janjevic, M., Improving policy support in city logistics: The contributions of a multi-actor multi-criteria analysis, In: Case Studies on Transport Policy, Vol. 6, Issue 4, pp. 554-563, Elsevier Science BV, ISSN 2213-624X, 2018, DOI: 10.1016/j.cstp.2018.07.003.

[8] Gnap, J., Semanova, S., Cernicky, L. et al., Logistika vstupu a vystupu nakladnych vozidiel do a z arealu U. S. Steel Kosice, s.r.o., University of Zilina, 2019.

[9] Mbiydzenyuy, G., Impact assessments of intelligent transport system performance in a freight transport corridor, In: IET Intelligent Transport Systems, Vol. 12, Issue 9, pp. 1071-1081, 25th World Congress on Intelligent Transport Systems (ITS), Copenhagen, 2018, INST Engineering Technology-IET, DOI: 10.1049/ietits.2018.5307.

[10] Cejka, J., Stopka, O., Effective Solutions to the Transport Distribution of Material by the Mayer Method, In: Advances in Science and Technology-Research Journal, Vol. 12, Issue 4, pp. 177-183, 2018, Lublin Univ. Technology, DOI: $10.12913 / 22998624 / 100364$.

[11] Poliak, M., Konecny, V., Factors determining the electronic tolling scope of road network, In: Journal of Economics, Vol. 36, Issue 7, pp. 712-731, Slovak Academic Press, 2008, ISSN 0013-3035.

[12] Lizbetinova, L., Fabera, P., Jambal, T., Caha, Z., Road Tax as an Economic Tool of the Support for the Development of Multimodal Transport in Selected EU States, In: 18th International Scientific Conference-LOGI 2017, MATEC Web of Conference, Vol. 134, DOI: $10.1051 /$ matecconf/201713400031.

[13] Jagelcak, J., Nakladanie a upevnovanie nakladu v cestnej doprave, 2015, University of Zilina.

[14] Jagelcak, J., Zamecnik, J., Kiktova M., Potential for Intermodal Transport of Chemical Goods in Slovakia, In: 18 th International Scientific Conference-LOGI 2017, MATEC Web of Conference, Vol. 134, 2017. DOI: 10.1051/matecconf/201713400021.
[15] Repisky, J., Teoria rozhodovania (2nd ed.), 2015, Nitra: Slovak University of Agriculture in Nitra, 154 p. ISBN 80-8069-475-3.

[16] Fiala, P., Jablonsky, J., Manas, M., Vicekriterialni rozhodovani (1st ed.), 1994, Praha: University of Economisc in Prague, 316 p. ISBN 80-7079-748-7.

[17] Sarkan, B., Gnap, J., Caban, M., Vrabel, J., Merczuk, A., Composition of exhaust gases of spark ignition engine under conditions of periodic inspecting of vehicles in Slovakia, In: Przemysl Chemiczny, Vol. 96, Issue 3, 2017, pp. 675-680, ISNN 0033-2496, DOI: 10.15199/62.2017.3.36.

[18] Skrucany, T., Kendra, M., Sarkan, B., Gnap, J., Software Simulation of an Energy Consumption and GHG Production in Transport, In: Tools of Transport Telematics (TST) 2015, Communications in Computer and Information Science, Vol. 531. Springer, Cham pp. 151-160, DOI: 10.1007/978-3-319-24577-5_15.

[19] Skrucany, T., Gnap, J., Energy Intensity and Greenhouse Gases Production of the Road and Rail Cargo Transport Using a Software to Simulate the Energy Consumption of a Train, In: 14th Transport Systems Telematics Conference (TST), 2014, Vol. 471, pp. 263 272, Springer-Verlag Berlin, ISSN 1865-0929.

[20] Petro, F., Konecny, V., Calculation of emissions from transport services and their use for the internalisation of external costs in road transport, In: Procedia Engineering, Vol. 192, 2017, pp. 677-682; Elsevier Science, DOI: 10.1016/j.proeng.2017.06.117.

[21] Li, S., Karatzoglou, A., Gentile, C., Collaborative Filtering Bandits, In: Proceedings of the 39th ACM SIGIR conference od Research and Development in Information Retrieval, Assoc Computing Machinery, 2016, pp. 539-548.

[22] Bouneffouf, D., Contextual Bandit Algorithm for Risk-Aware Recommender Systems, In: IEEE Congress on Evolutionary Computation (CEC) held as part of IEEE World Congress on Computational Intelligence (IEEE WCCI), Vancouver, CANADA, IEE, New York, 2016, pp: 4667-4674.

[23] Hao, F., Li, S., Min, G., et al., An Efficient Approach to Generating Location-Sensitive Recommendations in Ad-hoc Social Network Environments, In: IEEE TRANSACTIONS ON SERVICES COMPUTING; Vol. 8 Issue 3, 2015, pp. 520-533, DOI: 10.1109/TSC.2014.2401833.

[24] Gnap, J., Jagelcak, J., Gasparik, J., Stopka, O., Vaculik, J. et al., Tracking \& Tracing Analysis of Current Status and Futire Requirements; ChemLog T\&T, Association of chemical and pharmaceutical industry of the Slovak republic, University of Zilina, 2012. 